\title{
An Archaeological and Historical Survey of the Haase, Moy and Wiatrek Properties of the Conquista Project, Karnes County, Texas
}

\author{
A. Joachim McGraw
}

Follow this and additional works at: https://scholarworks.sfasu.edu/ita

Part of the American Material Culture Commons, Archaeological Anthropology Commons, Environmental Studies Commons, Other American Studies Commons, Other Arts and Humanities Commons, Other History of Art, Architecture, and Archaeology Commons, and the United States History Commons

Tell us how this article helped you.

This Article is brought to you for free and open access by the Center for Regional Heritage Research at SFA ScholarWorks. It has been accepted for inclusion in Index of Texas Archaeology: Open Access Gray Literature from the Lone Star State by an authorized editor of SFA ScholarWorks. For more information, please contact cdsscholarworks@sfasu.edu. 


\section{An Archaeological and Historical Survey of the Haase, Moy and Wiatrek Properties of the Conquista Project, Karnes County, Texas}

\section{Creative Commons License}

\section{(c) (1) (8)}

This work is licensed under a Creative Commons Attribution-NonCommercial 4.0 International License 


\author{
AN ARCHAEOLOGICAL AND HISTORICAL SURVEY \\ OF THE HAASE, MOY AND WIATREK PROPERTIES \\ OF THE CONQUISTA PROJECT, KARNES COUNTY, TEXAS
}

A. Joachim McGraw

Center for Archaeological Research

The University of Texas at San Antonio

Archaeological Survey Report, No. 81

1979 
List of Figures. . . . . . . . . . . . . . . . . ii Introduction ...................... . . . 1 Results of the Survey at the Haase Lease . . . . . . . . . . . 3 Results of the Survey in the Wiatrek Property. . . . . . . . . 6 Results of the Survey on the Moy Lease . . . . . . . . . . . 8 Summary of Surface Surveys at the Haase, Wiatrek and Moy Properties. . . 9 References cited .................... 11 


\section{LIST OF FIGURES}

Figure

Page

1. Map of Survey Area, Showing Site Locations. . . . . . . . . . 2

2. Selected Artifacts from $41 \mathrm{KA} 57,41 \mathrm{KA} 58$ and $41 \mathrm{KA} 50 \ldots 4$

3. Selected Artifacts from $41 \mathrm{KA} 50$ and $41 \mathrm{KA} 51$........ 5 


\section{INTRODUCTION}

During mid-Apri1 1979, personnel from the Center for Archaeological Research, The University of Texas at San Antonio, conducted an archaeological and historical survey of areas proposed for modification in the Conquista Project Continental 011 Company leases of the Haase, Moy and Wiatrek properties in northern Karnes County, Texas. The purpose of the surface investigation was to make an assessment of any archaeological or historical resources discovered on the properties and to make recommendations regarding such resources. The archaeological survey was conducted under the terms of an agreement between Mr. Morris Merritt of the Conquista Project and the Center for Archaeological Research, The University of Texas at San Antonio. Al1 field work was done under the direction of Dr. Thomas R. Hester, Director and Mr. Jack Eaton, Assistant Director.

The survey was conducted by A. Joachim McGraw and William Day, Technical Staff Assistants of the Center. The field crew investigated three separate but adjacent areas, totaling approximately 540 acres. The areas are located about eight kilometers southeast of Gillett, Texas in northern Karnes County (Fig. 1).

Field investigations consisted of a series of transects across all study areas, with a primary emphasis on the collection of diagnostic or otherwise significant artifacts. Distances to water sources, elevations, and specific environmental relationships were of particular consideration. Sites were recorded on standard site survey forms, and all materials were placed in plastic or paper bags and labeled as to temporary site number, type of collection, date and name of collector. Following field work, systematic site recording using the Smithsonian trinomial system was initiated, with pertinent 
This page has been

redacted because it

contains restricted

information. 
data sent to the Texas Archeological Research Laboratory, The University of Texas at Austin. All data and collected materials are on file with the Center for Archaeological Research, The University of Texas at San Antonio.

Four small prehistoric activity areas were discovered during the survey: one lithic workshop site was noted on the Haase lease; two lithic scatters were recorded on the Wiatrek property; and one lithic scatter was found on the Moy lease (see Fig. 1). The sites are discussed in more detail below, and Figs. 2 and 3 illustrate the types of artifacts collected.

\section{RESULTS OF THE SURVEY AT THE HAASE LEASE}

The surface of the Haase property had been extensively altered; however, one small prehistoric scatter was discovered. Located on the west bank of a smal1 tributary of Brushy Creek (see Fig. 1), the site consists of a light scatter of fire-reddened and cracked sandstone rock fragments and chert and other siliceous stone debris (secondary and tertiary flakes) for ca. 150 meters along the length of the bank's lower terrace. The site extends westward away from the drainage at least 75 meters and possibly more. Roughly oval in shape, the site generally follows the contours of the bank and appears extensively disturbed by past land-clearing activities. Although no hearths or other features were observed, the fire-fractured materials scattered in this area suggest other possible site functions in addition to lithic reduction processes. No diagnostic artifacts or intact features were noted at the extensively damaged site and no further work is recommended in this area. A summary of site data is presented below following the format of earlier Conquista Project archaeological site descriptions (cf. McGraw 1979). 

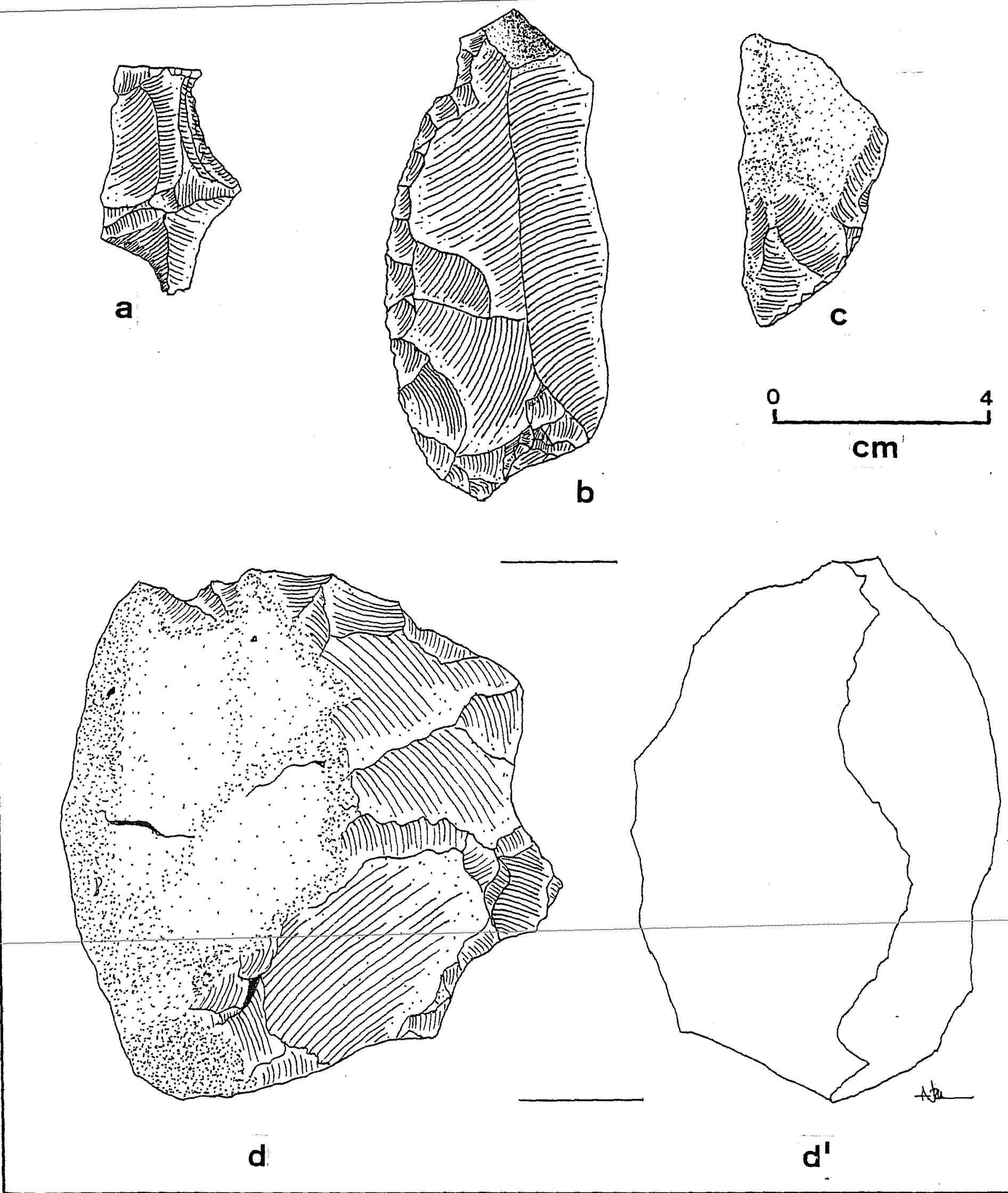

Figure 2. Selected Artifacts from $41 \mathrm{KA} \mathrm{57,41} \mathrm{KA} 58$ and $41 \mathrm{KA} 50$. a, $41 \mathrm{KA} 57$, tertiary flake, marginally trimmed on dorsal side; b, $41 \mathrm{KA} 58$, unifacial tool, retouched

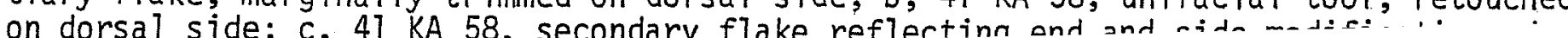



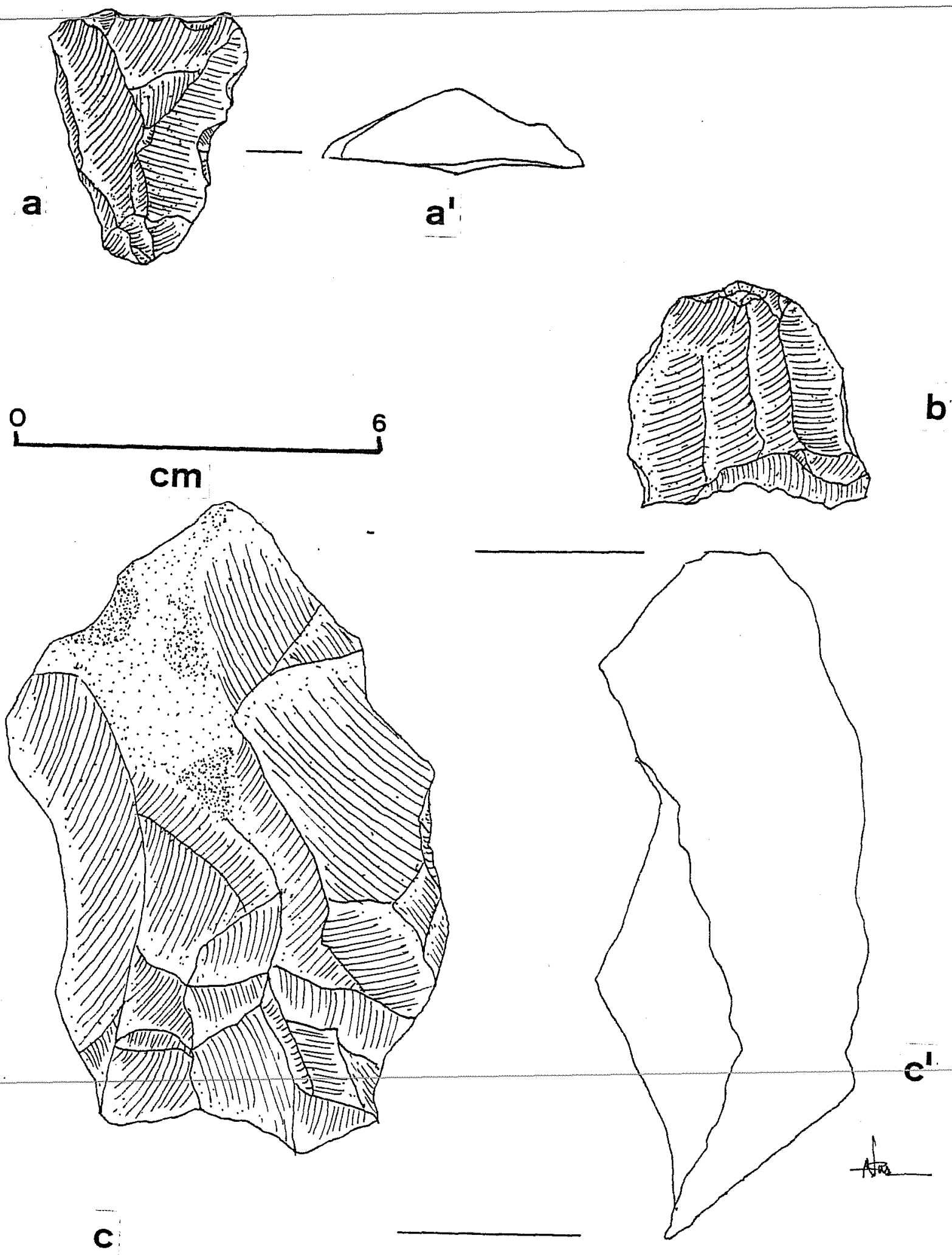

Figure 3. Selected Artifacts from $41 \mathrm{KA} 50$ and $41 \mathrm{KA} 51$. a, $41 \mathrm{KA} 51$, unifacial gougelike tool; a', side profile; 5,41 KA 50, tertiary flake reflecting blade-flake industry; c, 41 KA 51, large core; c', side profile, 
$4 J K A 57$

Location: Located in the Haase lease, on the west bank of a smal1, intermittent tributary of Brushy Creek. Cultural materials were scattered along the lower terrace areas.

Elevation: 400-410 feet above mean sea level, as noted on the USGS Garfield quadrangle map.

Description: A roughly oval lithic scatter ca. 150 meters north-south and 75 meters east to west, away from the drainage. Cultural materials consist of fire-reddened and fractured sandstone rock fragments, chert and other siliceous stone debris and petrified wood.

Type of Site: Temporary or intermittent lithic workshop, possible light campsite or other occupation activities.

Environmental characteristics: Site is located on low terrace adjacent to intermittent (presently flowing) drainage. Vegetation includes tall grasses, oak, mesquite and thorn brush. Portions of the topography appear to have been extensively damaged by past land clearing. Distance from water source: Horizontal, site is adjacent to bank; vertical, ca. 0-3 meters. Interpretation/Remarks: No further work is recommended.

\section{RESULTS OF THE SURVEY IN THE WIATREK PROPERTY}

Two archaeologicai sites were recorded on the Wiatrek lease; both are located on the western terraces of an intermittent drainage that bisects the lease north to south. Both sites are identified as light 1ithic scatters with other possible temporary activities; several fire-cracked sandstone rocks were noted in the area, although no direct associations with lithic debitage were observed. No diagnostic tools or projectile points were recovered at 
either site, and the general lack of cultural evidence combined with the disturbed conditions suggests no further work is necessary. Archaeological sites $41 \mathrm{KA} 58$ and $47 \mathrm{KA} 50$ are described in detait below:

$41 \mathrm{KA} 58$

Location: Located on the Wiatrek lease, ca. 75 meters west of an intermittent tributary of Brushy Creek and a small stock tank.

Elevation: 430 feet above mean sea level.

Description: A light lithic scatter ca. 100 meters in diameter. Several tertiary flakes and a dorsally retouched unifacial tool were observed in the site area (see Fig. 2). Several fire-fractured sandstone rock fragments may indicate other possible site functions. No features or chronologically diagnostic artifacts were collected.

Type of site: Lithic scatter reflecting former lithic workshop activities; other possible site functions.

Environmental characteristics: Site is located on broad and shallow gully near intermittent tributary. The site has been extensively damaged by past land clearing and is now populated by high grasses and thorn brush. Distance from water source: Horizontal, ca. 100 meters; vertical, ca. 6 meters. Interpretation/Remarks: No further work.

$41 \mathrm{KA} 50$

Location: Located on the Wiatrek lease, adjacent to west bank of intermittent drainage (see Fig. 1).

Elevation: 430 feet above mean sea level as noted on the USGS Garfield quadrangle.

Description: The site is a small, circular lithic scatter ca. 75 meters in diameter. Several fire-fractured rocks suggest other activities may have 
once taken place. Artifacts consisted of only several tertiary flakes and one core. No diagnostic artifacts or features were noted.

Type of site: Small lithic workshop; possible short-term occupation activities. Environmental characteristics: Low terrace adjacent to intermittent drainage. Vegetation consists of tall grasses, thorn brush, mesquite and prickly pear cactus.

Distance from water source: Horizontal, adjacent to drainage; vertical, ca. 2 meters.

Interpretation/Remarks: The lack of cultural material generally and diagnostic artifacts specifically, combined with the disturbed nature of the area, indicates that no further work is necessary.

\section{RESULTS OF THE SURVEY ON THE MOY LEASE}

Only one archaeological site was observed on the Moy Property. The site consisted of a moderate upland lithic scatter ca. 150 meters in diameter (see Fig. 1) and at least 500 meters from any present water source. Cultural materials yielded only lithic debitage in the form of tertiary siliceous stone flakes and a unifacial gouge-like tool of particularly poor quality material (see Fig. 3). The site appears to be a temporary activity area specializing in secondary lithic reduction processes. The area has been extensively damaged by land alterations, and no further work is recommended at the site. A detailed description is presented below:

\section{KA 51}

Location: Located on the Moy lease, in an open, upland field (see Fig. 1). Elevation: $450-460$ feet above mean sea level.

Description: A light lithic scatter ca. 150 meters in diameter with possible other site functions. A core, several flakes, and an end and side modified 
unifacial tool were collected, although no features or diagnostic artifacts were observed.

Type of site: Lithic scatter.

Environmental characteristics: Flat upland area covered by tall grasses. Nearest water source is ca. 500 meters from the site.

Distance from water source: Horizontal, minimum 500 meters; vertical, ca. 10 meters.

Interpretation/Remarks: The site has been extensively damaged by land clearing, and the lack of cultural materials suggests no further work is necessary.

SUMMARY OF SURFACE SURVEYS AT THE HAASE, WIATRER AND MOY PROPERTIES

The general survey area reflects a topography characterized by rolling, almost flat uplands dissected by intermittent drainages and often overgrown with prickly pear, mesquite and thorn brush flora. Archaeological sites in. these areas generally tend to be lithic reduction centers of limited size, dependent upon exposures of siliceous stone raw materials, and located various distances from water sources.

Kelly and Highley (1979) suggest that, of the recorded sites in Karnes County, about $30 \%$ may be defined as "7ithic procurement areas" and another $26 \%$ are sites of "undefined time periods" but which, in the main, presumably reflect various prehistoric lithic reduction activities. Both these descriptions are roughiy analogous to what this report defines as lithic scatters. For the purposes of this report, lithic scatters are defined as observable areas of prehistoric activity reflecting various stages of siliceous stone reduction processes involved in the manufacture and use of stone tools, projectile points and/or utilized lithic debris. Lithic scatters generally reflect little or no intrasite distributional patterns, presumably due to 
later site disturbance and short-term temporary, rather than recurrent or continual, occupational activity.

A11 four sites discovered during current survey operations were extensively damaged by past land clearing efforts. It should be noted that the site descriptions are based upon observable surface data only, and the present descriptions may not necessarily reflect the full extent of past site activities; evidences of occupation, such as hearths, may have long been destroyed by chain-dragging, plowing, or ather land-clearing methods.

Based on field survey operations and laboratory analysis of collected materials, none of the four recorded sites on the Haase, Wiatrek or Moy properties are recommended for further archaeological investigation. 


\section{REFERENCES CITED}

Kelly, T. C. and L. Highiey

1979 The Jackpump Project: An Archaeological Survey of Portions of Karnes and Gonzales Counties, Texas. Center for Archaeological Research, The University of Texas at San Antonio, Archaeological Survey Report 65.

McGraw, A. J.

1979 A Preliminary Archaeological Survey for the Conquista Project in Gonzales, Atascosa and Live Oak Counties, Texas. Center for Archaeological Research. The University of Texas at San Antonio, Archaeological Survey Report 76. 